\title{
Lethal short rib-polydactyly syndromes: further evidence for their overlapping in a continuous spectrum
}

\author{
Maria-Luisa Martínez-Frías, Eva Bermejo, Miguel Urioste, Héctor Huertas, Ignacio \\ Arroyo
}

ECEMC Coordinating

Group and

Departamento de

Farmacología,

Facultad de Medicina,

Universidad

Complutense, 28040

Madrid, Spain.

M L Martínez-Frias

ECEMC Coordinating

Group, Facultad de

Group, Facu

Universidad

Complutense, Madrid,

Spain.

E Bermejo

ECEMC Coordinating

Group and Hospital

Universitario San

Carlos, Facultad de

Medicina,

Universidad

Complutense, Madrid,

Spain.

M Urioste

ECEMC Peripheric

Group and Servicio de

Pediatría, Hospital

Gutiérrez Ortega,

Valdepeñas, Ciudad

Real, Spain.

H Huertas

ECEMC Peripheric

Group and Servicio de

Neonatología,

Hospital San Pedro de

Alcántara, Cáceres,

Spain.

I Arroyo

Correspondence to

Dr Martínez-Frias.

Received 30 March 1993

Revised version accepted

8 June 1993.

\begin{abstract}
We report two new unrelated infants with short rib-polydactyly syndrome (SRPS) whose clinical and radiological features overlap the four established forms of lethal SRPS, so that it is difficult to classify them into any one particular type. One of the babies had one of the most radiologically severe SRPS ever published. The patients presented here support the previously reported hypothesis that this group of disorders might be a continuous spectrum rather than separate entities.

( ( Med Genet 1993;30:937-41)
\end{abstract}

The features of the established lethal forms of short rib-polydactyly dwarfism syndromes (SRPS) $)^{1-4}$ overlap so much that it has become difficult to distinguish between them..$^{5-8}$ Consequently, there is controversy as to whether these types are the result of point mutations at different loci, different alleles at a single locus, or variability in the expression of the same mutant gene. ${ }^{59}$

We present two cases of SRPS that overlap all the previously described types. These cases were identified through the Spanish Collaborative Study of Congenital Malformations (ECEMC). ${ }^{10}$

\section{Case reports}

CASE 1

The female proband (fig 1, tables 1 and 2) was stillborn to a G2,P2, 33 year old mother and a 31 year old father. The parents were healthy and non-consanguineous. The family history was negative except for a distant relative with Down's syndrome.

The pregnancy was complicated by vaginal bleeding in the eighth month and the mother suffered from migraines. She was treated with antiemetics (during the first four months), allylstrenol (second and third months), aspirin (first and ninth months), propyphenazone and caffeine (first and third trimester), vitamin B (second month), and antibiotics (eighth month). She drank some beer at weekends. She had abdominal $x$ rays in the eighth month, but there were no occupational exposures.

Delivery was by spontaneous breech presentation at 40 weeks of gestation. Birth weight was $3600 \mathrm{~g}$ (75th centile) and head circumference $39 \mathrm{~cm}(>>97 \mathrm{th}$ centile). The macerated infant had hydrops (fig 1A, table 1), a flat face, flat nasal bridge, cleft upper lip, malformed ears, very short limbs, postaxial polydactyly, narrow chest, and a small, sexually ambiguous vaginal opening.

Radiological examination (fig 1B-D, table 2) showed frontal bossing, flat occiput, short cranial base (fig 1C), a marked shortening of the ribs and long tubular bones particularly in the mesomelic segment, small, rounded scapulae, small and flattened vertebral bodies (fig 1B), small iliac bones, and longitudinal metaphyseal spurs (fig 1D). There were premature ossification nuclei in the humeri and femora (fig 1B,D). In place of the tibia and fibula there was only one very short bone in each leg (fig 1D).

Necropsy and karyotype could not be performed.

CASE 2

This child (fig 2, tables 1 and 2), a female, was the second pregnancy of a G2,P2, 30 year old mother and a 33 year old father. They were healthy and non-consanguineous, even though three of the four grandparents came from the same small village. There was nothing remarkable in the family history except for a brother of the mother who had died shortly after birth of unknown cause.

The pregnancy of the proband was complicated by polyhydramnios, and the mother had mild morning sickness during the first two months. Fetal movements were first perceived at 4 months. The mother had taken mineral and multivitamin supplements from the fourth month to the end of pregnancy and occasionally aspirin. She had one beer and two cigarettes weekly, and one cup of coffee and a soft drink (cola) daily. There were no occupational exposures.

Breech delivery took place spontaneously at 28 weeks of gestation. The baby died two hours after birth. Her birth weight was $1220 \mathrm{~g}$ (75th to 90th centile). On physical examination, the infant had a narrow chest, short limbs, postaxial polydactyly of the right hand, and oedema (fig $2 \mathrm{~A}$, table 1 ).

Radiological examination (fig $2 \mathrm{~B}, \mathrm{C}$, table 2 ) showed marked shortening of the long bones and ribs and widening of the metaphyseal area with longitudinal spurs (see fig 2D for histology), which were also evident in the ribs and pelvis. The pelvic bones were abnormally contoured. The vertebral bodies were small. The femora were bowed and the tibiae and fibulae were equally short. Corticomedullary differen- 
(A)
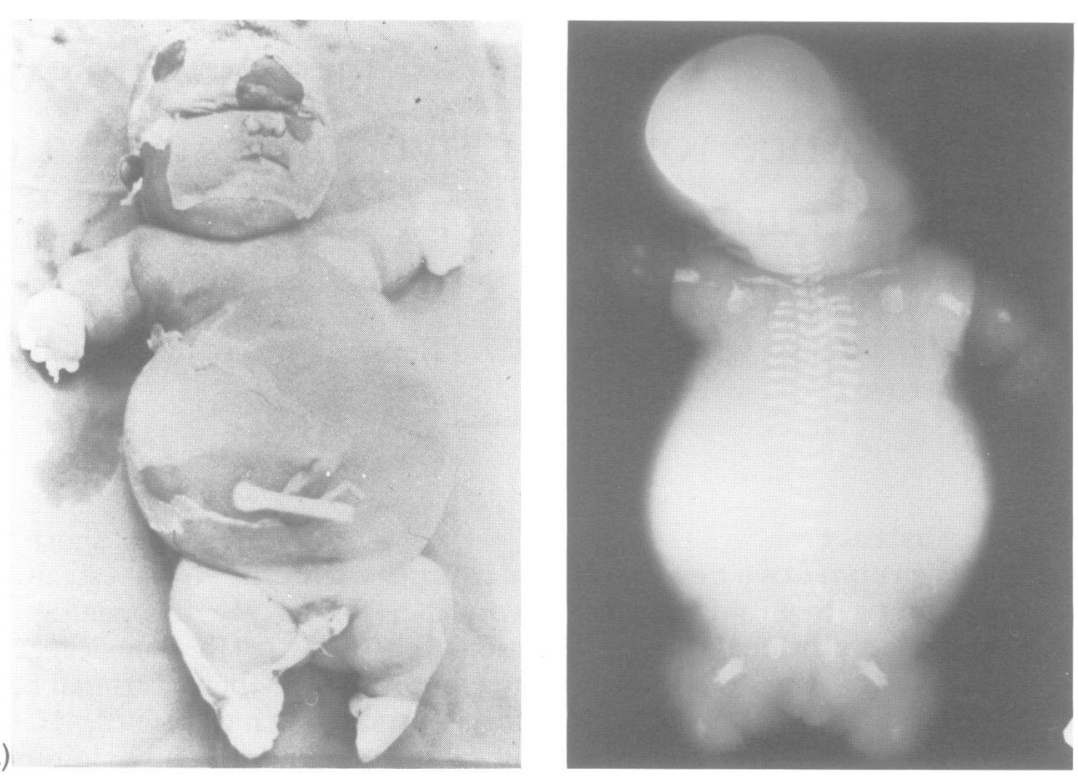

(B)

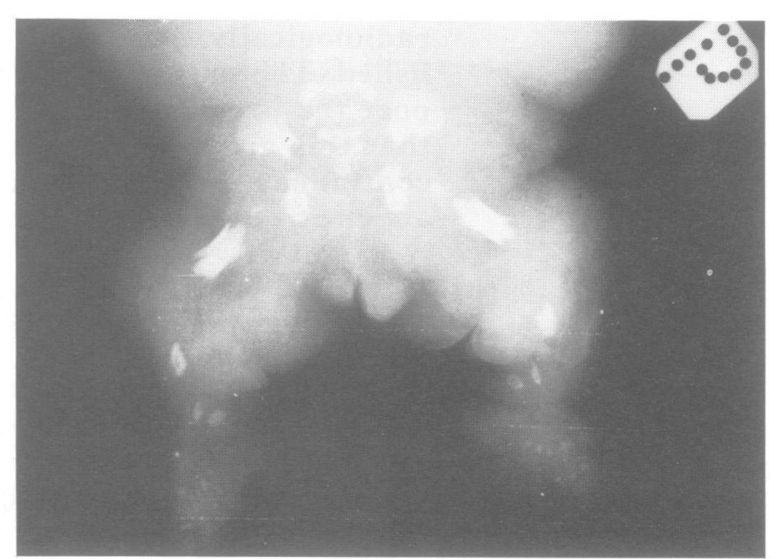

(D)

(C)

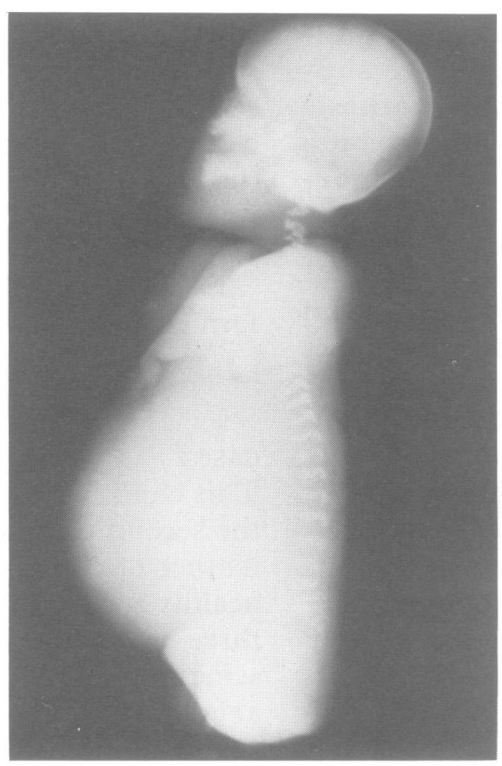

Figure 1 Case 1. (A) Postmortem photograph. (B) Anteroposterior x ray. (C) Lateral radiograph.

(D) Radiological examination of pelvis and lower limbs.

Table 1 Non-radiological diagnostic criteria for the four forms of SRPS and comparison with our cases.

\begin{tabular}{|c|c|c|c|c|c|c|}
\hline & \multicolumn{3}{|c|}{ Non-Majewski SRPS } & \multirow[b]{2}{*}{$\begin{array}{c}\text { Majewski } \\
\text { SRPS } \\
\text { (type II) }\end{array}$} & \multicolumn{2}{|c|}{ ECEMC cases } \\
\hline & $\begin{array}{l}\text { Saldino- } \\
\text { Noonan } \\
\text { (type I) }\end{array}$ & $\begin{array}{l}\text { Verma- } \\
\text { Naumoff } \\
\text { (type III) }\end{array}$ & $\begin{array}{c}\text { Beemer- } \\
\text { Langer } \\
\text { (type IV) }\end{array}$ & & 1 & 2 \\
\hline \multicolumn{7}{|l|}{ External appearance } \\
\hline Cleft upper lip & - & Pseudocleft & + & + & + & - \\
\hline Preaxial polydactyly & - & - & 1 case $^{11}$ & + & - & - \\
\hline Postaxial polydactyly & + & + & + & + & + & + \\
\hline Syndactyly & + & + & - & + & $?$ & - \\
\hline Omphalocele/umbilical hernia & - & - & + & - & - & - \\
\hline \multicolumn{7}{|l|}{ Systemic abnormalities } \\
\hline \multicolumn{7}{|l|}{ CNS } \\
\hline Holoprosencephaly & - & - & $+?^{12}$ & 1 case $^{13}$ & $?$ & - \\
\hline Hydrocephalus & - & - & $\begin{array}{l}+111314 \\
+>16\end{array}$ & $\begin{array}{l}+? ?^{15} \\
+?^{16}\end{array}$ & $?$ & $+-^{*}$ \\
\hline $\begin{array}{l}\text { NTD } \\
\text { Hynoplatic epiolottis }\end{array}$ & - & - & & $\begin{array}{l}+?+0 \\
+\end{array}$ & $?$ & $\begin{array}{l}- \\
-\end{array}$ \\
\hline Hypoplastic epiglottis & - & $\bar{t}$ & - & $\begin{array}{l}+ \\
+\end{array}$ & $?$ & $\bar{t}$ \\
\hline Urinary tract anomalies & + & + & + & + & $j$ & + \\
\hline Renal agenesis & + & - & - & - & $?$ & - \\
\hline \multirow{2}{*}{\multicolumn{7}{|c|}{ Other }} \\
\hline & & & & & & \\
\hline Polyhydramnios & + & + & + & + & $?$ & + \\
\hline Oligohydramnios & + & + & - & - & $?$ & - \\
\hline Inheritance & AR & AR & AR? & AR & & \\
\hline Consanguinity/affected sib & + & + & + & + & - & $-/$ sib \\
\hline Normal karyotype & + & + & + & + & ? & + \\
\hline Sex ratio $(M: F)$ & $4: 9$ & $5: 3$ & $8: 5$ & $1: 1$ & - & $=$ \\
\hline Sex & & & & & $\mathbf{F}$ & $\mathbf{F}$ \\
\hline
\end{tabular}

* Mild cerebral ventricular enlargement. 
Table 2 Radiological diagnostic criteria for the four forms of SRPS and comparison with our cases.

\begin{tabular}{|c|c|c|c|c|c|c|}
\hline & \multicolumn{3}{|c|}{ Non-Majewski SRPS } & \multirow[b]{2}{*}{$\begin{array}{c}\text { Majewski } \\
\text { SRPS } \\
\text { (type II) }\end{array}$} & \multicolumn{2}{|c|}{ ECEMC cases } \\
\hline & $\begin{array}{l}\text { Saldino- } \\
\text { Noonan } \\
\text { (type I) }\end{array}$ & $\begin{array}{l}\text { Verma- } \\
\text { Naumoff } \\
\text { (type III) }\end{array}$ & $\begin{array}{c}\text { Beemer- } \\
\text { Langer } \\
\text { (type IV) }\end{array}$ & & 1 & 2 \\
\hline Short cranial base & - & + & ? & - & + & + \\
\hline Macrocephaly & - & - & + & - & + & - \\
\hline Flat occiput & + & + & ? & - & + & - \\
\hline High clavicles & - & - & + & - & + & - \\
\hline Rounded scapulae & + & - & - & - & + & - \\
\hline Vertebral anomalies & + & + & + & - & + & $-*$ \\
\hline Pelvic abnormalities & + & + & + & - & + & + \\
\hline Abnormal contour & + & - & + & - & + & + \\
\hline Flat acetabulum & + & + & - & - & - & - \\
\hline Trident shaped & + & + & - & - & - & - \\
\hline Tibiae shorter than fibulae & - & - & - & + & $\dagger$ & - \\
\hline Ovoid tibia & - & - & - & + & $?$ & - \\
\hline Bowed femora & - & - & + & - & - & + \\
\hline Good corticomedullary differentiation & - & + & + & + & $?+$ & $+\ddagger$ \\
\hline Metaphyseal spurs & + & + & Min & Min & + & + \\
\hline Longitudinal & + & + & - & - & + & + \\
\hline Premature ossification nuclei & + & - & - & + & + & - \\
\hline
\end{tabular}

* Vertebral bodies were small, but the gestational age was 27 weeks.

+In place of the tibiae and fibulae there was only a very short bone.

$\ddagger$ Corticomedullary demarcation was difficult to assess.

Figure 2 Case 2. (A) Clinical appearance. (B) Anteroposterior $x$ ray. (C) Lateral radiograph. (D) Histological examination of the growth plate in long bones. 
tiation was difficult to assess (fig 2B). The cranial base was shortened.

Necropsy showed mild dilatation of the cerebral lateral ventricles, hypoplastic lungs, VSD, and hepatic fibrosis. There were also glomerular and renal tubular cysts, existing multiple visceral microhaemorrhages, and hyaline membrane disease.

Chromosome study performed on cultured skin fibroblasts showed a normal female karyotype, 46,XX.

This couple had a normal child who had been born one year before the proband, but we are aware that, more recently, they have had another infant with the same clinical appearance as the proband, also diagnosed as having SRPS (J I Rodríguez, personal communication).

\section{Discussion}

It has become apparent that there is an important overlap in both the clinical and radiological findings of the different types of lethal SRPS, ${ }^{5911}$ including the Majewski syndrome (type II SRPS), which had generally been considered to be easily distinguishable from the other types. ${ }^{17-19}$ In 1991, Yang et al ${ }^{12}$ stated that the Beemer-Langer SR(P)S shows clinical and radiological characteristics that allow it to be distinguished from the others as type IV. However, Hennekam ${ }^{11}$ considered that in some cases it is very difficult to distinguish BeemerLanger SR(P)S from type II (Majewski). In a recent report $^{8}$ we described two cases whose features overlapped all four types of lethal SRPS, and who also presented the most severe brain anomalies reported so far, such as anencephaly. One of the cases had an older sib who was also affected and these two sibs presented different clinical and radiological characteristics that were compatible with the Majewski type in one and with the non-Majewski SRPS type in the other; moreover, there was an older sib with anencephaly. Our conclusion was that, rather than representing new types of SRPS, these cases support the idea of a continuous spectrum which could include all the types of SRPS. The cases we describe here also support this conclusion since they have clinical and radiological features that overlap the four established types of SRPS; at least, we have been unable to classify them in any one of the existing types.

Case 1 showed radiological findings that seem to indicate one of the most extreme forms of lethal SRPS reported. She had a short cranial base, as is usually observed in SRPS type III, but she also had the flat occiput that has been recognised in types I and III. The rounded scapulae and vertebral anomalies together with pelvic abnormalities and the longitudinal metaphyseal spurs in this patient also make her condition compatible with SRPS type I or type III. Regarding the tibiae and fibulae, one of the two bones was absent bilaterally; it was impossible to be certain which one was missing, and the remaining one was very short. Absence of the tibia has been described recently by Sharma et $a l^{15}$ in a case with manifestations of both the hydrolethalus syndrome and SRPS type II (Majewski), and, in 1983, Walley et $a l^{20}$ reported non-ossified fibulae in a patient with the Majewski type of SRPS. On the other hand, the premature ossification of the proximal epiphyses of the humeri and femora are usually seen in type I and type II. The child also had a cleft upper lip as is observed in both types II and IV.

Case 2 also overlaps all the forms of SRPS. She had mild dilatation of the cerebral lateral ventricles (which is compatible with SRPS types II and IV), a short cranial base (seen in type III), pelvic abnormalities, non-ovoid tibiae the same length as her fibulae (which would favour types I, III, or IV), femoral bowing (type IV), and longitudinal metaphyseal spurs (which supports a diagnosis of types I or III). The absence of vertebral anomalies is compatible with SRPS type II. This case had hepatic fibrosis and renal cysts, as has been observed in some other cases of SRPS, including the non-lethal types such as Jeune syndrome and Ellis-van Creveld syndrome. Nevertheless, the clinical and radiological findings make the differential diagnosis of these non-lethal types easy.

These two cases once again show that it is very difficult to categorise some patients into only one of the four established types of SRPS, because they present some of the manifestations that are considered to be diagnostic criteria of more than one form. These findings support the existing hypothesis ${ }^{582021}$ of there being a single spectrum of SRPS that would include all the known types.

This work was supported in part by a grant from the Dirección General de Salud Pública, Ministerio de Sanidad y Consumo of Spain. We also thank C F Warren for her linguistic assistance.

1 Saldino RM, Noonan CD. Severe thoracic dystrophy with striking micromelia, abnormal osseus development including the spine, and multiple visceral anomalies. $A \mathcal{F} R$ 1972;114:257-63.

2 Majewski F, Pfeiffer RA, Lenz W, Müller R, Feil G, Seile $R$. Polysyndaktylie, verkürzte gliedmassen und genitalfehlbindungen: Kennzeichen eines selbständigen syndroms? Z Klinderheilkd 1971;111:118-38.

3 Verma IC, Bhargeva S, Agarwal S. An autosomal recessive form of lethal chondrodystrophy with severe thoracic narrowing, rhizo-acromelic type of micromelia, polydactyly and genital anomalies. Birth Defects 1975;11(6):16774.

4 Beemer FA, Langer LO, Klep-de Pater JM, et al. A new short rib syndrome: report of two new cases. $A m \mathcal{F} \mathrm{Med}$ Genet 1983;14:115-23.

5 Sillence DO. Invited editorial comment: non-Majewski short rib-polydactyly syndrome. Am $f$ Med Genet 1980;7:223-9.

6 Bernstein $R$, Isdale J, Pinto $M$, Du Toit Zaaijman J, Jenkins T. Short rib-polydactyly syndrome: a single or heterogeneous entity? A re-evaluation prompted by fou new cases. F Med Genet 1985;22:46-53.

7 Rodriguez JI, Gamallo C, Cuevas J, Pastor I, Collado F Síndrome de costilla corta-polidactilia con malformaciones viscerales múltiples. An Esp Pediatr 1980;13:80510

8 Martínez-Frías ML, Bermejo E, Urioste M, Egüés J, Lópe Soler JA. Short rib-polydactyly syndrome (SRPS) with anencephaly and other central nervous system anomalies: new type of SRPS or a more severe expression of known SRPS entity? Am $\mathcal{f}$ Med Genet (in press).

9 Cherstvoy ED, Lurie IW, Shved IA, Lazjuk GI, Ostrowskaya TI, Usojev SS. Difficulties in classification of the short rib-polydactyly syndromes. Eur $f$ Pediat 1980;133:57-61.

10 Martinez-Frias ML, Frias JL, Rodriguez-Pinilla E, et al. Value of clinical analysis in epidemiological research: the Spanish Registry sid 1991;41:192-5. 
11 Hennekam RCM. Short rib syndrome-Beemer type in sibs. Am f Med Genet 1991;40:230-3.

12 Yang SS, Roth JA, Langer LO Jr. Short rib syndrome Beemer-Langer type with polydactyly: a multiple congenital anomalies syndrome. Am f Med Genet

13 Nivelon-Chevalier A, Halfon D, Mabille JP. Chondrodysplasie letale à cotes courtes type Majewski. Diagnostic in utero. Pediatrie 1982;6:453-9.

14 Lin AE, Doshi N, Flom L, Tenenholz B, Filkins KL. Beemer-Langer syndrome with manifestations of an orofaciodigital syndrome. Am $\mathcal{f}$ Med Genet 1991;39:247-51.

15 Sharma AK, Phadke S, Chandra K, et al. Overlap between Majewski and hydrolethalus syndromes: a report of two cases. Am ₹ Med Genet 1992;43:949-53.

16 Tsai YC, Chang JM, Changchien CC, et al. Unusual short rib-polydactyly syndrome. Am F Med Genet 1992;44:316.

17 Spranger J, Grimm B, Weller M, Weissenbacher G, Herrmann J, Gilbert E, Krepler R. Short rib-polydactyly (SRP) syndromes, types Majewski and Saldino Noonan. Z Kinderheilkd 1974;116:73-94.

8 Jones KL. Smith's recognizable patterns of human malformations. Philadelphia: Saunders, 1989.

19 Gorlin RJ, Cohen MM, Levin LS. Syndromes of the head and neck. New York: Oxford University Press, 1990:21821.

20 Walley VM, Coates CF, Gilbert JJ, Valentine GH, Davies EM. Brief clinical report: short rib-polydactyly syndrome, Majewski type. Am $\mathcal{F}$ Med Genet 1983;14:445-52.

21 Bidot-López P, Ablow RC, Ogden JA, Mahoney MJ. A case of short rib polydactyly. Pediatrics 1978;61:427-32. 